\title{
Oxidative Dissolution of Biogenic Uraninite in Groundwater at Old Rifle, CO
}

\author{
Kate M. Campbell, ${ }^{+, *}$ Harish Veeramani, ${ }^{\ddagger, \#}$ Kai-Uwe Ulrich, ${ }^{\S, \nabla}$ Lisa Y. Blue, ${ }^{\S, \bigcirc}$ Daniel E. Giammar, \\ Rizlan Bernier-Latmani, ${ }^{\ddagger}$ Joanne E. Stubbs, ${ }^{\|, \bullet}$ Elena Suvorova, ${ }^{\ddagger}$ Steve Yabusaki, ${ }^{\perp}$ Juan S. Lezama-Pacheco, ${ }^{\|}$ \\ Apurva Mehta," Philip E. Long, ${ }^{\perp}$ and John R. Bargar" \\ ${ }^{\dagger}$ U.S. Geological Survey, 3215 Marine Sreet, Boulder, Colorado 80303, United States \\ ${ }^{\ddagger}$ Environmental Microbiology Laboratory, École Polytechnique Fédérale de Lausanne, Lausanne, CH 1015, Switzerland \\ ${ }^{\S}$ Washington University in Saint Louis, Saint Louis, Missouri 63130, United States \\ "Stanford Synchrotron Radiation Lightsource, 2575 Sand Hill Road, Menlo Park, California 94025, United States \\ ${ }^{\perp}$ Pacific Northwest National Laboratory, Richland, Washington 99352, United States
}

Supporting Information

ABSTRACT: Reductive bioremediation is currently being explored as a possible strategy for uranium-contaminated aquifers such as the Old Rifle site (Colorado). The stability of U(IV) phases under oxidizing conditions is key to the performance of this procedure. An in situ method was developed to study oxidative dissolution of biogenic uraninite $\left(\mathrm{UO}_{2}\right)$, a desirable U(VI) bioreduction product, in the Old Rifle, CO, aquifer under different variable oxygen conditions. Overall uranium loss rates were 50-100 times slower than laboratory rates. After accounting for molecular diffusion through the sample holders, a reactive transport model using laboratory dissolution rates was able to predict overall uranium loss. The presence of biomass further retarded diffusion and oxidation rates. These results confirm the importance of diffusion in controlling in-aquifer U(IV) oxidation rates. Upon retrieval, uraninite was found to be free of $\mathrm{U}(\mathrm{VI})$, indicating dissolution occurred via oxidation and removal of surface atoms. Interaction of groundwater solutes such as $\mathrm{Ca}^{2+}$ or silicate with uraninite surfaces also may retard in-aquifer $U$ loss rates. These results indicate that the

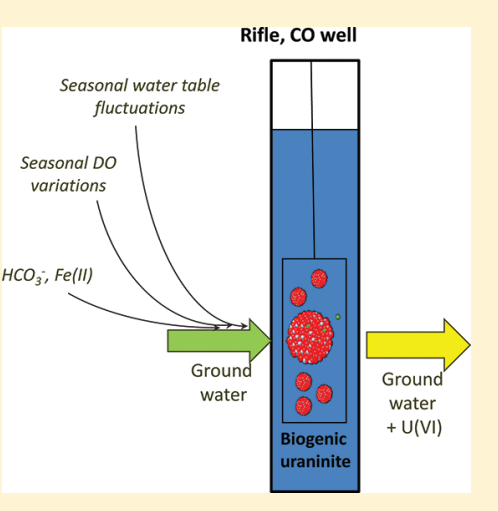
prolonged stability of $\mathrm{U}(\mathrm{IV})$ species in aquifers is strongly influenced by permeability, the presence of bacterial cells and cell exudates, and groundwater geochemistry.

\section{INTRODUCTION}

The legacy of uranium $(\mathrm{U})$ ore extraction and processing has left many sites with U-contaminated groundwater, even after extensive tailings removal and remediation projects. Reductive bioremedation is currently being explored as a possible strategy for sites with excess groundwater uranium concentrations. Bioremediation at the Old Rifle site (Colorado) has been performed by amending the aquifer with acetate to stimulate the growth of natural metal- and sulfate-reducing microbial communities, and the reduction of $\mathrm{U}(\mathrm{VI})$ to $\mathrm{U}(\mathrm{IV}){ }^{1-3}$ Owing to the relatively low solubility of U(IV), this process substantially decreases the concentration of dissolved $U$ in the groundwater. ${ }^{1,4,5}$ Uraninite $\left(\mathrm{UO}_{2(\mathrm{~s})}\right)$ is one of the most desirable products, and its longevity under reducing conditions is evidenced by its importance in low-temperature sedimentary uranium ore deposits, ${ }^{6,7}$ and recent work by our group (unpublished results) shows it may occur in aquifers following bioreduction.

Metal- and sulfate-reducing bacteria are capable of enzymatically reducing $\mathrm{U}(\mathrm{VI})$ to uraninite (e.g., refs 8-10), as well as to other forms of $U(I V)$, such as $U(I V)$ adsorbed to biomass and minerals. ${ }^{11-14}$ Of these products, uraninite is the only well-characterized material for which thermodynamic and kinetic constants are known. It therefore provides the best available proxy for other forms of U(IV) and can be used to constrain U(IV) stability in sediments. Biogenic uraninite is almost universally reported to be a nanoparticulate $(2-5 \mathrm{~nm})$ solid, although it tends to form larger agglomerates ${ }^{15,16}$ and exhibits structural similarity even when produced by a phylogenetically diverse group of organisms. ${ }^{10}$ Whereas the oxidative dissolution of biogenic uraninite has been studied in the laboratory (e.g., refs 17-21), its behavior under aquifer conditions has not been investigated. The rates of uraninite oxidation in groundwater are expected to differ from those measured under well-stirred laboratory conditions because of the sensitivity of uraninite reaction rates to the presence of various trace groundwater solutes ${ }^{22}$ and to diffusionlimited conditions in aquifer pore spaces. ${ }^{23}$ Developing a quantitative understanding of the effect of chemical conditions and kinetics of $\mathrm{U}(\mathrm{IV})$ oxidation under aquifer conditions is therefore important to

Received: February 11, 2011

Accepted: September 12, 2011

Revised: $\quad$ August 26, 2011

Published: September 12, 2011 
understanding the performance of stimulated reductive bioremediation and developing appropriate site management practices. This study was designed to elucidate the effect of groundwater geochemistry, particularly variable dissolved oxygen (DO), on oxidative dissolution of uraninite.

Of potential oxidants (e.g., DO, nitrate, manganese oxides, iron oxides, and natural organic matter $\left.{ }^{17,21,24-27}\right)$, DO is particularly important because of its relative abundance. At circumneutral $\mathrm{pH}$ in the presence of dissolved inorganic carbon (DIC), oxidation of biogenic uraninite by $\mathrm{DO}$ proceeded by oxidation of U(IV) atoms, followed by rapid removal of surface U(VI) from the surface by bicarbonate complexation. ${ }^{19}$ The same study showed that the solubility and dissolution rates of biogenic uraninite are similar to those of coarse-grained $\mathrm{UO}_{2.00}{ }^{18,19}$

The objectives of this study were to extend this previous work into aquifer conditions where uraninite would be exposed to ambient DO, bicarbonate, $\mathrm{Ca}^{2+}$, silicate, sulfate, and other species. We deployed biogenic uraninite into wells at the Old Rifle site using novel membrane-walled cells that allowed for diffusive solute exchange with groundwater but prevented dispersive loss of uraninite particles and invasion of bacteria. Two wells with contrasting groundwater chemistry were utilized to probe the impact of the master variable, DO: one being a typical oxic background well, and the other located in a zone of natural bioreduction, characterized by suboxic conditions, higher Fe(II) concentrations, and evidence of $\mathrm{U}(\mathrm{IV})$ in nearby sediments.

\section{MATERIALS AND METHODS}

Rifle, CO Field Site. The shallow, unconfined aquifer has residual $U$ contamination from $U$ ore processing. The groundwater composition has been reported previously. ${ }^{1,28}$ Generally, the aquifer has low but measurable amounts of $\mathrm{DO}$, has $\sim 8 \mathrm{mM}$ sulfate, and $\mathrm{Ca}^{2+}$ and $\mathrm{HCO}_{3}{ }^{-}$are typically near equilibrium with calcite solubility. Groundwater U concentrations are $0.4-1.8 \mu \mathrm{M}$, and the primary aqueous species are $\mathrm{U}(\mathrm{VI})$-carbonate and $\mathrm{Ca}-$ $\mathrm{U}(\mathrm{VI})$-carbonate ternary species at typical groundwater $\mathrm{pH}$ ( $\mathrm{pH} 7.2-7.4)$. Nitrate concentrations are low $(<20 \mu \mathrm{M})$, and it is unlikely to compete with DO as a potential oxidant.

Wells used for uraninite incubations were chosen to bracket a range of DO concentrations. The wells used for this study were B-02, a background well, and P-103, located in a naturally bioreduced zone. The groundwater at B-02 is typical of the Rifle site. In contrast, P-103 is naturally suboxic to anoxic with reduced $\mathrm{U}(\mathrm{IV})$ phases present in the surrounding sediment. Neither B-02 nor P-103 has been exposed to acetate amendment.

Biogenic Uraninite Synthesis. Biogenic uraninite installed as cleaned oxide was precipitated by Shewanella oneidensis strain MR-1 to facilitate comparison to previous studies. ${ }^{29,30}$ The solid was sequentially washed with $1 \mathrm{M} \mathrm{NaOH}$, hexane and $100 \mathrm{mM}$ $\mathrm{NaHCO}_{3}$ to remove biomass and residual U(VI). Biogenic uraninite to be installed with its host biomass intact was produced under similar conditions by a Shewanella isolate from Rifle groundwater (as required by the Colorado Environmental Protection Agency), but was not washed with $\mathrm{NaOH}$, bicarbonate, or hexane so that the biomass-uraninite association was preserved. The cleaned uraninite produced by the isolate was structurally comparable to the uraninite produced by MR-1 (data not shown). In addition, this material contained a small fraction of monomeric U(IV) complexes associated with the biomass. ${ }^{13}$ A uraninite slurry (either with biomass (P103-BIOMASS-slurry, B02-BIOMASS-slurry) or without biomass (P103-CLN-slurry,
B02-CLN-slurry)) was placed directly into a sample tube for deployment, used to create a $\mathrm{UO}_{2}$-doped gel puck for mass balance determination (described below), or archived for characterization and dissolution rate measurements. The biomass associated with the uraninite was not expected to grow under deployment conditions due to the absence of electron donor.

Biogenic Uraninite-Doped Gel Pucks for Mass Balance. Polyacrylamide gel pucks ${ }^{31}$ doped with uraninite were prepared to evaluate mass loss rates during oxidative dissolution; mass loss could not be evaluated from slurry samples. The gels acted as an inert matrix that did not dissolve nor substantially affect the uraninite reactivity. ${ }^{31,32}$ Biogenic uraninite was homogeneously distributed within the gel puck, with an average variation of $10 \%$. One half of each puck was retained to determine total U loading per unit weight of each gel. A fraction of the other half was cut into slabs (approximately $2 \mathrm{~cm} \times 3 \mathrm{~mm} \times 2 \mathrm{~mm}$ ) and transferred to a sample cell (described below) for deployment. Scanning electron microscopy (SEM) measurements on the gel pucks show the uraninite to be present in the pucks in loose agglomerations of individual nanoparticles, similar to particles not embedded in gel (Supporting Information (SI) Figure S1). Upon recovery from the wells, the gel fractions were weighed and equilibrated with $5 \mathrm{~mL}$ of concentrated $\mathrm{HNO}_{3}$. The solution was then analyzed for U by ICP-OES (Perkin-Elmer, Plasma 2000). Uranium loss from the gel pucks was determined by calculating the difference in $U$ concentration in gel pucks before and after deployment. Gels were doped with washed uraninite (P103CLN-gel, B02-CLN-gel) or with biomass-associated uraninite (P103-BIOMASS-gel, B01-BIOMASS-gel).

Permeable Sample Cells, Assembly, And Deployment. Permeable sample cells were developed to maintain biogenic uraninite in contact with groundwater. Cells were constructed from $2 \mathrm{~mL}$ polyethylene tubes with three vertical slots along the body of the tube ( $\sim 50 \%$ of surface area removed). Cellulose ester dialysis membrane (Spectrum Spectra/Por, $10000 \mathrm{Da}$ ) was bonded to the tube to cover the slots. The tubes were loaded in the field in a $\mathrm{N}_{2}$-filled anaerobic chamber with either a suspension of biogenic uraninite ( $\sim 50$ to $300 \mathrm{mg}$ of uraninite per tube, for spectroscopy) or uraninite-doped polyacrylamide gel pucks ( 5-10 mg uraninite per tube, for mass balance). The maximum diffusive path within the gel pucks in tubes was $<3 \mathrm{~mm}$ (SI Figure S2). Diffusion of $\mathrm{KNO}_{3}$ through the membrane on a tube was used to determine the overall mass transfer coefficient for the tubes $\left(1.08 \times 10^{-4} \mathrm{~cm} / \mathrm{s}\right)$; a tube loaded with $0.1 \mathrm{M}$ $\mathrm{KNO}_{3}$ fully equilibrated with $100 \mathrm{~mL}$ of surrounding solution within two to three days, whereas diffusion of water and solutes through a gel puck is on the order of hours for a $2-3 \mathrm{~mm}$ gel. ${ }^{31,32}$ The tubes were secured in a plastic holder (SI Figure S2); the entire assembly was deployed in the well about $5 \mathrm{~m}$ below the ground surface and at least $1 \mathrm{~m}$ below the water table for the duration of the experiment. The entire well below the water table was screened.

Uraninite was deployed on February 11, 2009 and recovered on May 5, 2009 (83 days of reaction). A second set of gel puck samples was deployed on July 16, 2009 and recovered on October 26, 2009 (102 days of reaction). Both $\mathrm{NaOH}$-washed uraninite and biomassassociated uraninite slurries were deployed in July, whereas only $\mathrm{NaOH}$-washed uraninite was deployed in February (SI Table S1).

Characterization of Biogenic Uraninite. Lattice parameter, crystallite size, local structure, and the composition of uraninite recovered from the slurry-filled tubes after in situ reaction was determined by synchrotron powder X-ray diffraction (XRD), 
X-ray absorption near edge structure (XANES), extended X-ray absorption fine structure (EXAFS), and chemical digestion.

XRD data were collected at SSRL beamline 7-2 in transmission geometry on a 6-circle Huber diffractometer using an energy dispersive Vortex detector placed behind $1 \mathrm{mrad}$ Soller slits. X-ray wavelengths $(0.7646-0.7647 \AA)$ were calibrated using a $\mathrm{LaB}_{6}$ standard. A subset of each archived and deployed uraninite slurry sample was dried anaerobically, gently disaggregated, and loaded into $0.3 \mathrm{~mm}$ diameter borosilicate glass capillaries and sealed with epoxy. Data were collected from 1.0 to $14.5 \AA^{-1} \mathrm{Q}$ $0.02 \AA^{-1}$ step size. The recorded count rates were normalized to those of the incident beam. Lattice parameters and nominal crystallite sizes were determined by Rietveld refinement using the Generalized Structure Analysis System of Larson and Von Dreele $^{33}$ and the user interface EXPGUI. ${ }^{34}$

For XANES and EXAFS analysis, a subset of deployed slurry sample ( $\sim 10 \mathrm{mg})$ was either dried and diluted with boron nitride or used wet without dilution, loaded into Al X-ray cells $(1 \mathrm{~mm}$ thick) with Kapton windows and stored in the anaerobic chamber until immediately prior to analysis. The samples were mounted in a liquid $\mathrm{N}_{2}$ cryostat. $\mathrm{U} \mathrm{L}_{\mathrm{III}}$-edge transmission spectra were collected using a typical beam size of 0.2 to $0.5 \mathrm{~mm}$ at SSRL beamlines 11-2 and 4-1, using detuned $\mathrm{Si}$ (220) double-crystal monochromators. EXAFS spectra were processed using SIXPACK ${ }^{35}$ Backscattering phase and amplitude functions required for fitting of spectra were obtained from FEFF8. ${ }^{36}$

Chemical digestions of an aliquot of deployed slurry sample were performed in sequence: separation of the dissolved phase, $1 \mathrm{mM} \mathrm{HCl}$ wash (adsorbed phase), aqua regia digest (digest). A subset of each archived sample of uraninite was digested in aqua regia for comparison. The fractions were analyzed for a suite of 26 elements by ICP-MS (Agilent 7500ce).

Electron Microscopy. Samples for electron microscopy were prepared from gel pucks by drying the pucks in an anaerobic chamber atmosphere at $30^{\circ} \mathrm{C}$, cutting thin sections of the resin, and placing sections on a copper grid. Bright field transmission electron microscopy (BFTEM), high-resolution TEM (HRTEM) and selected area electron diffraction (SAED) were performed with a FEI CM300UT/FEG microscope (Eindhoven, Netherlands). Phase identification was derived from SAED patterns and Fourier transforms of the HRTEM images using the JEMS software. ${ }^{37}$ Direct chemical information was obtained by X-ray energy dispersive spectroscopy (EDS) mapping.

Dissolution Rate of $\mathrm{UO}_{2}$ in Rifle Artificial Ground water. The dissolution rate of $\mathrm{NaOH}$-washed biogenic uraninite was measured in Rifle artificial groundwater and ultrapure water using stirred continuous-flow reactors (CFR) previously used for the quantification of $\mathrm{UO}_{2}$ dissolution rates in solutions of simpler compositions. ${ }^{19,20}$ Duplicate reactors $(12.6 \mathrm{~mL})$ were loaded with $\sim 1 \mathrm{~g} / \mathrm{L}$ suspensions of $\mathrm{UO}_{2}$ and sealed with $0.2 \mu \mathrm{m}$ polycarbonate filter membranes (Millipore). Influent solutions were prepared with compositions to simulate Rifle groundwater (Rifle Artificial Groundwater, RAGW, SI Table S2). These solutions were prepared at $\mathrm{pH} 8.5$ and contained $1 \mathrm{mM}$ dissolved inorganic carbon as well as $\mathrm{Na}^{+}, \mathrm{K}^{+}, \mathrm{Ca}^{2+}, \mathrm{Mg}^{2+}, \mathrm{Cl}^{-}$, and $\mathrm{SO}_{4}{ }^{2-}$. $\mathrm{A} \mathrm{pH}$ of 8.5 was selected to enable future comparisons of the rates with those previously measured. ${ }^{20}$ Influent solutions were sparged with gas to provide the desired DO concentration. For the first stage of the experiment, the influents were sparged with a $5 \% / 95 \% \mathrm{H}_{2} / \mathrm{N}_{2}$ mixture in the presence of a Pd catalyst to remove residual oxygen; $\mathrm{CO}_{2}$ loss was not significant. In the second stage, the solution was sparged with a gas mixture of $1 \%$
$\mathrm{O}_{2}$ and $99 \% \mathrm{~N}_{2}$, and the final stage used air as the sparging gas $\left(8.6 \mathrm{mg} / \mathrm{L} \mathrm{O}_{2}\right)$. Each stage of the experiment was operated for a time equivalent to 40 residence times or longer. The reactor effluents were sampled, filtered $(0.020 \mu \mathrm{m}$, Whatman, alumina membranes), acidified with $1 \% \mathrm{HNO}_{3}$, and analyzed by ICP-MS for dissolved $U$. The effluent was regularly monitored for the flow-rate, $\mathrm{pH}$, and $\mathrm{DO}$ as measured with an in-line electrode (Microelectrodes, Inc.).

Dissolution rates normalized to surface area $\left(R_{\mathrm{n}}, \mathrm{mol} \mathrm{m}^{-2}\right.$ $\mathrm{min}^{-1}$ ) were calculated from the steady-state effluent concentration of $\mathrm{U}\left([\mathrm{U}]_{\mathrm{ss}}, \mathrm{mol} / \mathrm{L}\right)$, the hydraulic residence time $\left(t_{\text {res }}, \sim 6\right.$ min for this study), the specific surface area of the biogenic uraninite (SSA, $\left.50.1 \mathrm{~m}^{2} / \mathrm{g}\right)$, and the solids loading of the reactor ([solid], g/L) $\left(\right.$ eq $\left.1^{18}\right)$.

$$
R_{\mathrm{n}}=\frac{[U]_{\mathrm{ss}}}{t_{\mathrm{res}} \cdot \mathrm{SSA} \cdot[\mathrm{solid}]}
$$

The steady-state effluent concentration was determined by finding the best fit of a simple model for CFR behavior to the experimental data. Intrinsic dissolution rate constants were then calculated from the dissolution rates using an approach used previously. ${ }^{18}$

Reactive Transport Model. A multicomponent reactive transport model was developed to predict diffusion-limited biogenic uraninite dissolution in membrane tubes under groundwater conditions present in well B-02. Key elements of the model include a $6 \mathrm{~mm}$ diameter zone of $6 \mathrm{mg}$ of uraninite centered in the $8 \mathrm{~mm}$ diameter membrane cell with advection of ambient solution outside the membrane. Symmetry was invoked allowing modeling of half the domain with a no-flux boundary condition along the line of symmetry. Diffusion was assumed to be the only active transport process in the tube and membrane. The diffusion coefficient of the membrane was adjusted to reproduce the results of the membrane tube $\mathrm{KNO}_{3}$ diffusion experiment. The initial aqueous condition within the cylinder was $\mathrm{pH} 7$ solution without $\mathrm{U}$ or DO. A pH 7 solution in equilibrium with an oxygen partial pressure of $0.00243 \mathrm{~atm}$ and no $\mathrm{U}$ was assumed to be flowing tangentially by the membrane (SI Figure S3).

The reaction network employed $\mathrm{H}^{+}, \mathrm{UO}_{2}^{2+}$ (as a proxy for dissolved $\mathrm{U}(\mathrm{VI})$ ), and $\mathrm{O}_{2(\mathrm{aq})}$ as primary species and solved with the following reactions and stability constants:

$$
\begin{aligned}
& \mathrm{OH}^{-}+\mathrm{H}^{+}=\mathrm{H}_{2} \mathrm{O}(\log \mathrm{K}=13.991) \\
& \mathrm{O}_{2}(\mathrm{~g})=\mathrm{O}_{2}(\mathrm{aq})(\log \mathrm{K}=-2.893) \\
& \mathrm{UO}_{2(\mathrm{~s})}+4 \mathrm{H}^{+}=\mathrm{U}^{4+}+2 \mathrm{H}_{2} \mathrm{O}(\log \mathrm{K}=-1.5) \\
& \mathrm{U}^{4+}+\mathrm{H}_{2} \mathrm{O}+\frac{1}{2} \mathrm{O}_{2(\mathrm{~g})}=\mathrm{UO}_{2}{ }^{2+}+2 \mathrm{H}^{+}(\log \mathrm{K}=32.4999)
\end{aligned}
$$

A transition state rate law was employed for uraninite; no other solid phases were needed in the model. An intrinsic rate of $10^{-9.5}$ $\mathrm{mol} / \mathrm{m}^{2} / \mathrm{s}$ and surface area $50.1 \mathrm{~m}^{2} / \mathrm{g}$ was used for uraninite. ${ }^{19}$ The research code used for these calculations is based on finite column discretization using a Cartesian grid. A global implicit solution of the transport and reactions was used with a backward Euler numerical scheme. 


\section{RESULTS AND DISCUSSION}

Dissolution Rate of Biogenic Uraninite in RAGW. The dissolution rate of biogenic uraninite increased with increasing $\mathrm{DO}$ in the RAGW/CFR experiments (Figure 1). Because the solutions contained $1 \mathrm{mM}$ DIC and $5 \mathrm{mM} \mathrm{Ca}$, the $\mathrm{U}(\mathrm{VI})$ produced by uraninite oxidation is mobilized from the surface through formation of soluble $\mathrm{Ca}-\mathrm{U}(\mathrm{VI})$-carbonate complexes. ${ }^{19}$ The major cations and anions present in the artificial groundwater, especially DIC, increased the rate of uraninite dissolution approximately 3 -fold at high $p \mathrm{O}_{2}$ compared to ultrapure water.

Groundwater Composition. Groundwater compositions at wells B-02 (oxic) and P-103 (suboxic/anoxic) are listed in SI Table S3. The primary difference between these wells was DO concentration; B-02 had 5- to 10-fold higher DO than P-103 during the 83-day experiment, and 2- to 3-fold higher during the 102-day experiment. Variation in DO values was driven by summer peak streamflow in the Colorado River, which seasonally elevates the water table and traps DO. P-103 had consistently higher $\mathrm{Fe}(\mathrm{II})$ concentrations (15-27 $\mu \mathrm{M}$ compared to $4-9 \mu \mathrm{M}$ in $\mathrm{B}-02)$. The major ion chemistry, $\mathrm{pH}$, and alkalinity of the wells were otherwise similar. Thus, contrasting chemical behavior for uraninite recovered from these wells should be attributed primarily to differences in DO.

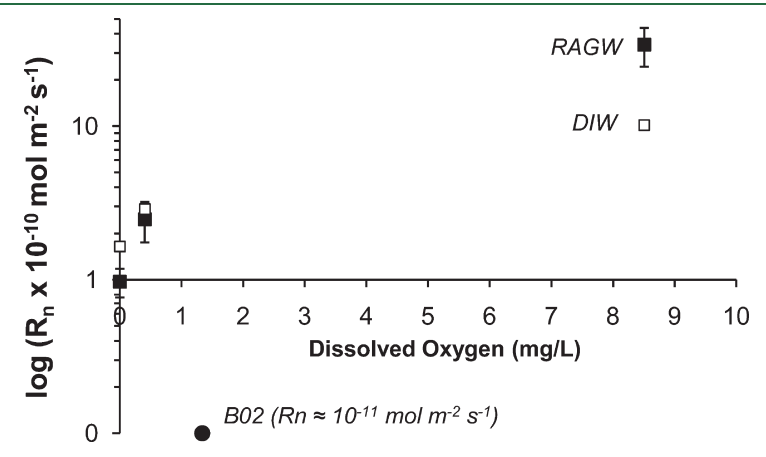

Figure 1. Uranium dissolution rates $\left(R_{\mathrm{n}}\right)$ for $\mathrm{NaOH}$-washed biogenic uraninite dissolution in ultrapure water (DIW, $\square$.) and Rifle artificial groundwater $(\mathrm{RAGW}, \boldsymbol{\square})$ at different levels of dissolved oxygen at $\mathrm{pH} \approx$ 8.5 and with $1 \mathrm{mM}$ DIC in the CFR experiment. Also shown are overall $\mathrm{U}$ loss rates from gel puck samples deployed in well B-02 (๑, B02-CLNgel, 102-day reaction). P103-CLN-gel (83-day and102-day reaction) showed negligible loss and was therefore not included. Error bars are mostly smaller than symbol size.
Uraninite Mass Balance in Field-Reacted Gel Pucks. During the 102-day deployment, more dissolution was observed in the $\mathrm{NaOH}$-cleaned uraninite in B-02 (55\% lost) compared to P-103 (no substantial loss) (Figure 2). The decrease in U loss cannot be attributed to the presence of monomeric $\mathrm{U}(\mathrm{IV})$, which oxidizes faster than uraninite (unpublished results). The presence of biomass, however, reduced the amount of uraninite lost to only $11 \%$ in both P-103 and B-02 (Figure 2). Since the biomass should not have been metabolically active or provided a significant redox buffer, we conclude that its impact was due to retarded diffusion of $U$ and DO.

Molecular-Scale Structure and Oxidation State of Biogenic Uraninite. XANES spectra for the archived and deployed uraninite slurry samples ( $\mathrm{NaOH}$-cleaned and biomass-associated) are consistent with that of biogenic uraninite (SI Figure S4), indicating that $\mathrm{U}(\mathrm{VI})$ products did not accumulate during in-well exposure.

X-ray diffraction data and Rietveld refinement results are given in Table 1 and fits are shown in SI Figure S5. The lattice parameters refined to 5.464, 5.464, and $5.468 \AA$ for the unreacted archive sample, B-02-CLN-slurry and P-103-CLN-slurry samples, respectively. These values are in agreement with one another and with previously published lattice parameters for both biogenic and abiotic uraninite $(5.46-5.47 \AA) .{ }^{30}$ In comparison, the lattice constant for $\mathrm{U}_{4} \mathrm{O}_{9}$ is $5.44 \AA$. The crystallite sizes estimated from Rietveld refinement $(\sim 2.1 \mathrm{~nm})$ do not vary significantly among the reacted and archive samples, nor do the calculated strains $(\sim 3 \%)$, which are interpreted as semiquantitative measures of strain gradients between crystallite cores and surfaces. ${ }^{30}$ The fit derived crystallite size compares well to the TEM-derived estimates of $1.5 \mathrm{~nm}$ (SI Figure S6). These observations indicate that the uraninite unit cell structure and size were not substantially altered by interaction with the groundwater during the incubation period. No other phases (e.g., U(VI) minerals) were observed in any postreacted slurry sample.

The EXAFS, Fourier transforms (FTs, Figure 3), and fit results (SI Table S4) from the $\mathrm{NaOH}$-cleaned slurry samples are similar to one-another. The observed $\mathrm{U}-\mathrm{U}$ distances, and coordination numbers (CNs) are consistent with biogenic uraninite. ${ }^{10,30}$ Because crystallite size does not vary significantly, the increase in the $3.8 \AA(R+\mathrm{d} R) \mathrm{U}$-U FT frequency following submersion in the Rifle aquifer indicates that the particles became more ordered after reaction in groundwater, implying increased stability.

Mechanism of Uraninite Corrosion. Corrosion of biogenic uraninite (oxidative dissolution) follows one of two different
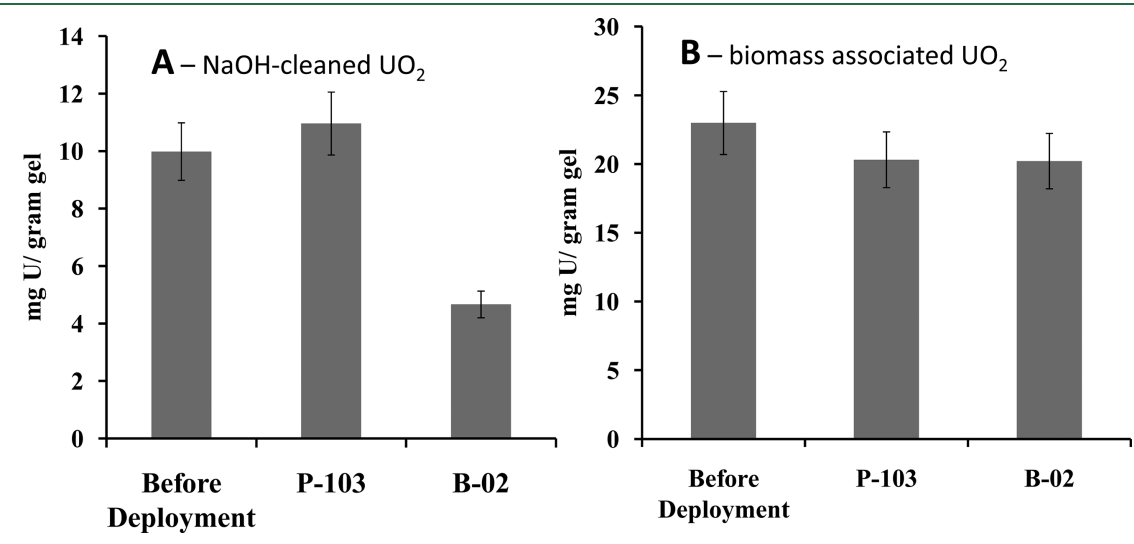

Figure 2. U losses from gel pucks deployed in wells after 102 days compared to an aliquot of unreacted gel puck. Left panel (A) is NaOH-washed biogenic uraninite (B02-CLN-Gel and P103-CLN-Gel), and right panel (B) is uraninite including biomass from rifle isolate (B02- BIOMASS -Gel and P103- BIOMASS -Gel). 
Table 1. Results of Rietveld Refinement of Powder X-ray Diffraction Data on Unreacted Samples and NaOH-Cleaned Slurry Samples Deployed for 102 Days at Rifle ${ }^{a}$

\begin{tabular}{lccccc}
\multicolumn{1}{c}{ sample } & $a(\AA)$ & crystallite size $(\mathrm{nm})$ & strain $(\%)$ & $R_{\mathrm{wp}}$ & $R\left(F^{2}\right)$ \\
unreacted biogenic uraninite (control) & $5.464(1)$ & $2.07(5)$ & $2.8(4)$ & 0.032 & 0.016 \\
B02-CLN-slurry & $5.464(1)$ & $2.15(5)$ & $3.1(4)$ & 0.034 \\
P103-CLN-Slurry & $5.468(1)$ & $2.09(4)$ & $2.7(3)$ & 0.031
\end{tabular}

${ }^{a}$ Estimated standard deviation (ESD) in final digit is shown in parentheses. Unreacted control is the parent material, which was not incubated in Rifle wells. These are model-dependent, statistical ESDs. In the cases of crystallite size and strain gradient, they are based on a simple, empirical peak shape profile that assumes all peak broadening arises from crystallite size and strain gradient. The actual ESDs are likely several times larger. $R_{\mathrm{wp}}$ is the crystallographic $R$-factor for the whole pattern and $R\left(F^{2}\right)$ is the $R$-factor for the Bragg peaks.
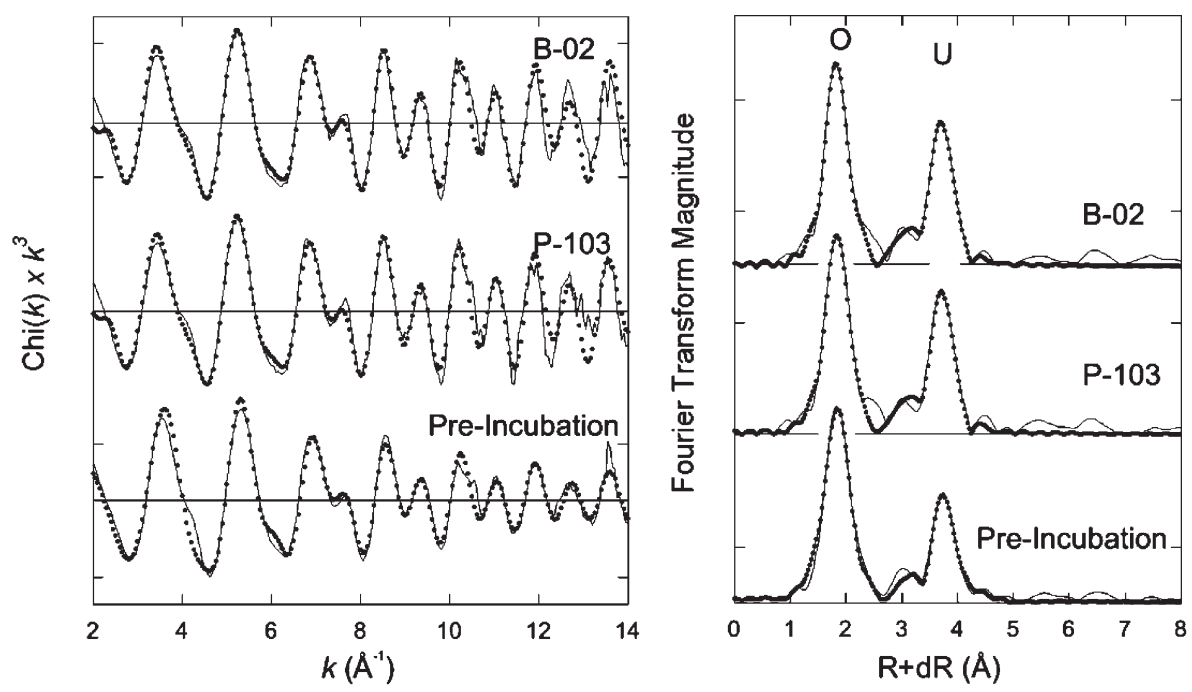

Figure 3. EXAFS (left) and corresponding Fourier Transforms (right) for biogenic uraninites incubated at the Old Rifle aquifer in membrane tubes (samples B02-CLN-Slurry and P103-CLN-Slurry, 102-day reaction, and unreacted archive sample). Dotted lines represent fits to the data.

processes. $^{18,22}$ Under conditions of high DO, low dissolved bicarbonate, and/or diffusion limited conditions, oxidation of surface $\mathrm{U}(\mathrm{IV})$ atoms can be fast relative to dissolution of the oxidized surface species, resulting in accumulation of $\mathrm{U}(\mathrm{VI})$ solids. In contrast, if bicarbonate is present in relative abundance, $\mathrm{DO}$ is moderate or low in concentration, and diffusion is not limiting, then oxidized surface U(VI) atoms can be removed more rapidly than they can accumulate. There was no evidence for accumulation of $\mathrm{U}(\mathrm{VI})$ or $\mathrm{UO}_{2+x}$ in the field-reacted samples, in accordance with the presence of excess bicarbonate. Moreover, reactive transport modeling predicted nonoxidative uraninite dissolution to be insignificant. Therefore, we conclude that the oxidized surface $U$ atoms were removed by dissolved bicarbonate, and uraninite surface atom oxidation was the rate-limiting step.

Effect of DO on Uraninite Oxidation under Ambient Groundwater Conditions. In well B-02, the rate of dissolution is approximately 2 orders of magnitude slower than what we would predict based on the RAGW CFR results (Figure 1). Possible explanations for this observation include: (a) kinetic limitation of diffusion across the cell membranes, (b) passivation of uraninite by adsorption, (c) structural incorporation of groundwater solutes not present in RAGW, and/or (d) cementation of uraninite nanoparticles (i.e., mechanical isolation of uraninite from solution). The differing $\mathrm{pH}$ between the CFR (8.5) and Rifle groundwater (7.2) should not significantly affect the mechanism or rates of oxidation because uranyl-carbonato complexes are the dominant aqueous $\mathrm{U}(\mathrm{VI})$ species at both $\mathrm{pH}$ values. ${ }^{19}$

A reactive transport model was used to estimate the affect of transmembrane diffusion of DO and $\mathrm{U}(\mathrm{VI})$ on the overall loss rates under the groundwater conditions present in well B-02. Model results indicate that $52 \%$ of the uraninite $(\sim 3 \mathrm{mg}$ of uraninite in the model) should be lost over the 102-day experiment. This compares well with the amount lost from the gel pucks (without biomass), estimated to be $50 \%$ (3-5 $\mathrm{mg}$ of uraninite). This comparison and model sensitivity analysis (SI) suggests that diffusion is a key control on the rate of uraninite dissolution in the system (explanation (a)). Since the prediction uses a laboratory-derived dissolution rate for uraninite, the in-gel $\mathrm{U}$ loss rate (no diffusive barriers) is overall consistent with that derived from published laboratory values. ${ }^{19}$

In an aquifer sedimentary environment, diffusion is complex and controlled by a number of factors, including pore size and shape, particle size, porosity, and diffusivity. A spectrum of diffusion limited conditions are expected. The experiment presented here is expected to be analogous to a condition intermediate in the range of pore-scale environments present in aquifers; the prolonged stability of uraninite in wells may also apply to diffusion-limiting sediments. In high conductivity flow regimes, the effect of diffusion on oxidative dissolution would be expected to be relatively minor. However, in fine-grained sediments (such as those common in naturally bioreduced zones), the presence of diffusive barriers should be expected to strongly retard U oxidation. 
Precipitation of iron sulfides and calcite and accumulation of biomass during biostimulation is expected to decrease sediment permeability, which would provide additional diffusive barriers in the subsurface.

Silicate and Ca have previously been shown to substantially inhibit uraninite corrosion when adsorbed on the surface of synthetic uraninite at concentrations similar to Rifle groundwater. ${ }^{22,38}$ Dissolved silicate was absent in RAGW but was present at $\sim 0.3 \mathrm{mM}$ in the groundwater of the present study. The reaction of DO with $\mathrm{Fe}^{2+}$ (aq) should preclude $\mathrm{Fe}$ (II) inhibiting dissolution. Additionally, there was no difference in extractable Fe between the archive sample, P103-CLN-slurry, and B02-CLN-slurry, indicating that Fe(II) oxidation did not supplant uraninite oxidation. Therefore, it is possible that the presence of $\mathrm{Ca}, \mathrm{Si}$, or other solute-uraninite interactions could have contributed to the observed slow uraninite loss rates (explanation (b)).

The chemical extraction results show that Ca was substantially enriched in the strongly bound fraction compared to the unreacted uraninite $(0.2-0.3 \mathrm{~mol} \mathrm{Ca} / \mathrm{mol} \mathrm{U}$, SI Table S5). Ca was approximately 10 -fold more concentrated in the strongly bound fraction than in the adsorbed phase. EDS mapping also showed $\mathrm{Ca}$ (as well as $\mathrm{Si}$ and $\mathrm{P}$ ) to be associated with biogenic uraninite in gel pucks from after reaction in well B-02 (SI Figures S8 and S9). There were no substantial differences in chemical extraction results between wells B-02 and P-103. Incorporation of $\mathrm{Ca}$ into uraninite structural sites beyond a dopant concentration of approximately $1 \%(0.01 \mathrm{~mol} \mathrm{Ca} / \mathrm{mol} \mathrm{U})$ would have caused a distortion and weakening of the EXAFS U-U shell, as seen for Mn(II), ${ }^{29}$ but was not observed in the present data set. No evidence of crystalline calcite or other phases besides uraninite was detected by XRD or HRTEM (SI Figure S5), nor was there evidence that uraninite nanoparticles were cemented together by such phases. Therefore, Ca must have been present as an adsorbed species and/or an amorphous solid, and explanations (c) and (d) can be neglected.

Environmental Implications. It has been hypothesized that the oxidation of biogenic uraninite in aquifers would proceed faster than synthetic or bulk $\mathrm{UO}_{2}$ because of its nanoparticulate nature. ${ }^{9}$ The present study has shown that the stability of biogenic uraninite with respect to oxidative dissolution is complex and is likely to be strongly influenced by the groundwater geochemistry and association with diffusional barriers. In particular, diffusion limitations to the rates of supply and removal of $\mathrm{DO}$ and $\mathrm{U}(\mathrm{VI})$ to/from uraninite, as well as association with biomass and adsorbed solutes, are expected to substantially prolong the lifespan of biogenic uraninite, even when the groundwater is oxic. These same factors are expected to retard oxidation of other forms of U(IV) in aquifers. The slow oxidation/release of uranium observed in this study, even under oxic conditions, suggests than uranium may be sustainably released from either naturally or artificially reduced sediments over long periods of time. This general model offers a potential mechanism to explain plume persistence at contaminated sites such as Old Rifle that contain sediment-hosted naturally reduced uranium.

\section{ASSOCIATED CONTENT}

S Supporting Information. Additional methods, SEM/TEM images of uraninite embedded in gel pucks, constituents of RAGW, model schematic and results, XRD data and fitting results, XANES spectra, EXAFS fits, chemical extraction data,
STEM, EDS mapping and spectra. This material is available free of charge via the Internet at http://pubs.acs.org.

\section{AUTHOR INFORMATION}

\section{Corresponding Author}

*Phone: (303) 541-3035; fax (303) 541-3084; e-mail: kcampbell@ usgs.gov.

\section{Present Addresses}

\#Department of Geosciences, Virginia Polytechnic and State University, Blacksburg, Virginia 24060

${ }^{\nabla}$ BGD Soil and Groundwater Laboratory, 01219 Dresden, Germany

${ }^{\circ}$ Covalent Research Technologies, LLC, Lexington, Kentucky 40507

'Consortium for Advanced Radiation Sources, University of Chicago, Chicago, Illinois 60637

\section{ACKNOWLEDGMENT}

We thank Richard Dayvault, David Traub, Carol Morris, Aaron Gooch, Joe Rogers, Michael Hay, and Tanya Gallegos. Funding for this project was provided by a DOE-OBER grant to SLAC (work package 2009-SLAC-10006), grant DE-FG0206ER64227 to EPFL, Swiss NSF grants 20021-113784 and 200020-126921/1, and USGS/NRC postdoctoral program. Portions of this research were carried out at the Stanford Synchrotron Radiation Light Source, a national user facility operated by Stanford University on behalf of the U.S. Department of Energy Office of Basic Energy Sciences. Any use of trade, product, or firm names is for descriptive purposes only and does not imply endorsement by the U.S. Government.

\section{REFERENCES}

(1) Anderson, R. T.; Vrionis, H. A.; Ortiz-Bernad, I.; Resch, C. T.; Long, P. E.; Dayvault, R.; Karp, K.; Marutzky, S.; Metzler, D. R.; Peacock, A.; White, D. C.; Lowe, M.; Lovley, D. R. Stimulating the in situ activity of Geobacter species to remove uranium from the groundwater of a uranium-contaminated aquifer. Appl. Environ. Microbiol. 2003, 69 (10), 5884-5891.

(2) Finneran, K. T.; Anderson, R. T.; Nevin, K. P.; Lovley, D. R. Potential for bioremediation of uranium-contaminated aquifers with microbial U(VI) reduction. Soil Sediment Contam. 2002, 11 (3), 339-357.

(3) Lovley, D. R; Phillips, E. J. P. Reduction of uranium by Desulfovibrio desulfuricans. Appl. Environ. Microbiol. 1992, 58 (3), 850-856.

(4) Lovley, D. R.; Phillips, E. J. P. Bioremediation of uranium contamination with enzymatic uranium reduction. Environ. Sci. Technol. 1992, 26 (11), 2228-2234.

(5) Wu, W. M.; Carley, J.; Gentry, T.; Ginder-Vogel, M. A.; Fienen, M.; Mehlhorn, T.; Yan, H.; Caroll, S.; Pace, M. N.; Nyman, J.; Luo, J.; Gentile, M. E.; Fields, M. W.; Hickey, R. F.; Gu, B.; Watson, D.; Cirpka, O. A.; Zhou, J.; Fendorf, S.; Kitanidis, P. K.; Jardine, P. M.; Criddle, C. S. Pilot-scale in situ bioremedation of uranium in a highly contaminated aquifer. 2. Reduction of $\mathrm{U}(\mathrm{VI})$ and geochemical control of U(VI) bioavailability. Environ. Sci. Technol. 2006, 40 (12), 3986-3995.

(6) Bargar, J. R.; Bernier-Latmani, R.; Giammar, D. E.; Tebo, B. M. Biogenic uraninite nanoparticles and their importance for uranium remediation. Elements 2008, 4 (6), 407-412.

(7) Plant, J. A.; Simpson, P. R.; Smith, B.; Windley, B. F. Uranium ore deposits - Products of the radioactive earth. Rev. Mineral. and Geochem. 1999, 38, 254-319.

(8) Lovley, D. R.; Phillips, E. J. P.; Gorby, Y. A.; Landa, E. R. Microbial reduction of uranium. Nature 1991, 350 (6317), 413-416.

(9) Wall, J. D.; Krumholz, L. R. Uranium reduction. Annu. Rev. Microbiol. 2006, 60, 149-166. 
(10) Sharp, J. O.; Schofield, E. J.; Veeramani, H.; Suvorova, E. I.; Kennedy, D. W.; Marshall, M. J.; Mehta, A.; Bargar, J. R.; Bernier-Latmani, R. Structural similarities between biogenic uraninites produced by phylogenetically and metabolically diverse bacteria. Environ. Sci. Technol. 2009, 43 (21), 8295-8301.

(11) Khijniak, T. V.; Slobodkin, A. I.; Coker, V.; Renshaw, J. C.; Livens, F. R.; Bonch-Osmolovskaya, E. A.; Birkeland, N. K.; MedvedevaLyalikova, N. N.; Lloyd, J. R. Reduction of uranium(VI) phosphate during growth of the thermophilic bacterium Thermoterrabacterium ferrireducens. Appl. Environ. Microbiol. 2005, 71 (10), 6423-6426.

(12) Fletcher, K. E.; Boyanov, M. I.; Thomas, S. H.; Wu, Q.; Kemner, K. M.; Löfler, F. E. U(VI) reduction to mononuclear U(IV) by desulfitobacterium species. Environ. Sci. Technol. 2010, 44 (12), 4705-4709.

(13) Bernier-Latmani, R.; Veeramani, H.; Vecchia, E. D.; Junier, P.; Lezama-Pacheco, J. S.; Suvorova, E.; Sharp, J. O.; Wigginton, N. S.; Bargar, J. R. Non-uraninite products of microbial U(VI) reduction. Environ. Sci. Technol. 2010, 44, 5104-5111.

(14) Suzuki, Y.; Banfield, J. F. Geomicrobiology of uranium. Rev. Mineral. Geochem. 1999, 38 (1), 393-432.

(15) Suzuki, Y.; Kelly, S. D.; Kemner, K. M.; Banfield, J. F. Nanometresize products of uranium bioreduction. Nature 2002, 419 (6903), 134.

(16) Burgos, W. D.; McDonough, J. T.; Senko, J. M.; Zhang, G.; Dohnalkova, A. C.; Kelly, S. D.; Gorby, Y.; Kemner, K. M. Characterization of uraninite nanoparticles produced by Shewanella oneidensis MR-1. Geochim. Cosmochim. Acta 2008, 72 (20), 4901-4915.

(17) Moon, H. S.; Komlos, J.; Jaffé, P. R. Biogenic U(IV) oxidation by dissolved oxygen and nitrate in sediment after prolonged $\mathrm{U}(\mathrm{VI}) / \mathrm{Fe}(\mathrm{III}) / \mathrm{SO}_{4}{ }^{2-}$ reduction. J. Contam. Hydrol. 2009, $105(1-2)$, $18-27$.

(18) Ulrich, K. U.; Ilton, E. S.; Veeramani, H.; Sharp, J. O.; BernierLatmani, R.; Schofield, E. J.; Bargar, J. R.; Giammar, D. E. Comparative dissolution kinetics of biogenic and chemogenic uraninite under oxidizing conditions in the presence of carbonate. Geochim. Cosmochim. Acta 2009, 73 (20), 6065-6083.

(19) Ulrich, K. U.; Singh, A.; Schofield, E. J.; Bargar, J. R.; Veeramani, H.; Sharp, J. O.; Bernier-Latmani, R.; Giammar, D. E. Dissolution of biogenic and synthetic $\mathrm{UO}_{2}$ under varied reducing conditions. Environ. Sci. Technol. 2008, 42 (15), 5600-5606.

(20) Komlos, J.; Peacock, A.; Kukkadapu, R. K.; Jaffé, P. R. Longterm dynamics of uranium reduction/reoxidation under low sulfate conditions. Geochim. Cosmochim. Acta 2008, 72 (15), 3603-3615.

(21) Senko, J. M.; Kelly, S. D.; Dohnalkova, A. C.; McDonough, J. T.; Kemner, K. M.; Burgos, W. D. The effect of U(VI) bioreduction kinetics on subsequent reoxidation of biogenic U(IV). Geochim. Cosmochim. Acta 2007, 71 (19), 4644-4654.

(22) Shoesmith, D. W. Fuel corrosion processes under waste disposal conditions. J. Nucl. Mater. 2000, 282 (1), 1-31.

(23) Brusseau, M. L.; Rao, P. S. C. Modeling solute transport in structured soils: A review. Geoderma 1990, 46, 169-192.

(24) Wu, W. M.; Carley, J.; Luo, J.; Ginder-Vogel, M. A.; Cardenas, E.; Leigh, M. B.; Hwang, C.; Kelly, S. D.; Ruan, C.; Wu, L.; Van Nostrand, J.; Gentry, T.; Lowe, K.; Mehlhorn, T.; Carroll, S.; Luo, W.; Fields, M. W.; Gu, B.; Watson, D.; Kemner, K. M.; Marsh, T.; Tiedje, J.; Zhou, J.; Fendorf, S.; Kitanidis, P. K.; Jardine, P. M.; Criddle, C. S. In situ bioreduction of uranium (VI) to submicromolar levels and reoxidation by dissolved oxygen. Environ. Sci. Technol. 2007, 41 (16), 5716-5723.

(25) Ginder-Vogel, M.; Criddle, C. S.; Fendorf, S. Thermodynamic constraints on the oxidation of biogenic $\mathrm{UO}_{2}$ by $\mathrm{Fe}(\mathrm{III})$ (hydr)oxides. Environ. Sci. Technol. 2006, 40 (11), 3544-3550.

(26) Gu, B.; Yan, H.; Zhou, P.; Watson, D. B.; Park, M.; Istok, J. Natural humics impact uranium bioreduction and oxidation. Environ. Sci. Technol. 2005, 39 (14), 5268-5275.

(27) Sani, R. K; Peyton, B. M.; Dohnalkova, A.; Amonette, J. E. Reoxidation of reduced uranium with iron(III) (hydr)oxides under sulfate-reducing conditions. Environ. Sci. Technol. 2005, 39 (7), 2059-2066.

(28) Yabusaki, S. B.; Fang, Y.; Long, P. E.; Resch, C. T.; Peacock, A. D.; Komlos, J.; Jaffe, P. R.; Morrison, S. J.; Dayvault, R. D.; White, D. C.; Anderson, R. T. Uranium removal from groundwater via in situ biostimulation: Field-scale modeling of transport and biological processes. J. Contam. Hydrol. 2007, 93 (1-4), 216-235.

(29) Veeramani, H.; Schofield, E. J.; Sharp, J. O.; Suvorova, E. I.; Ulrich, K. U.; Mehta, A.; Giammar, D. E.; Bargar, J. R.; Bernier-Latmani, R. Effect of $\mathrm{Mn}(\mathrm{II})$ on the structure and reactivity of biogenic uraninite. Environ. Sci. Technol. 2009, 43 (17), 6541-6547.

(30) Schofield, E. J.; Veeramani, H.; Sharp, J. O.; Suvorova, E.; Bernier-Latmani, R.; Mehta, A.; Stahlman, J.; Webb, S. M.; Clark, D. L.; Conradson, S. D.; Ilton, E. S.; Bargar, J. R. Structure of biogenic uraninite produced by Shewanella oneidensis strain MR-1. Environ. Sci. Technol. 2008, 42 (21), 7898-7904.

(31) Campbell, K. M.; Root, R.; O’Day, P. A.; Hering, J. G. A gel probe equilibrium sampler for measureing arsenic porewater profiles and sorption gradients in sediments: I. Laboratory development. Environ. Sci. Technol. 2007, 42, 504-510.

(32) Kneebone, P. E.; O’Day, P. A.; Jones, N.; Hering, J. G. Deposition and fate of arsenic in iron- and arsenic-enriched reservoir sediments. Environ. Sci. Technol. 2002, 36 (3), 381-386.

(33) Larson, A. C.; Von Dreele, R. B. General Structure Analysis System (GSAS), LANL Report No. LAUR 96-748, 2004, .

(34) Toby, B. H. EXPGUI, a graphical user interface for GSAS. J. Appl. Crystallogr. 2001, 34, 210-213.

(35) Webb, S. M. SIXPack: A graphical user interface for XAS analysis using IFEFFIT. Phys. Scri. 2005, T115, 011-1014.

(36) Rehr, J. J. A., R. C.; Zabinsky, S. I. High-order multiplescattering calculations of X-ray absorption fine structure. Phys. Rev. Lett. 1992, 69 (23), 3397-3400.

(37) Stadelmann, P., http://cimewww.epfl.ch/people/stadelmann/ jemswebsite/jems.html (accessed May 2010).

(38) Santos, B. G.; Noël, J. J.; Shoesmith, D. W. The influence of silicate on the development of acidity in corrosion product deposits on SIMFUEL ( $\left.\mathrm{UO}_{2}\right)$. Corros. Sci. 2006, 48 (11), 3852-3868. 